Omni-Akuatika, 12 (2): 92-98, 2016
ISSN: 1858-3873 print / 2476-9347 online
Research Article

\title{
Identifikasi Kerang Kapah Di Pantai Timur Pulau Tarakan
}

\author{
Abdul Jabarsyah ${ }^{1)}$ and Takeshi Arizono ${ }^{2)}$ \\ ${ }^{1)}$ Fakuitas Perikanan dan IImu Kelautan Universitas Borneo Tarakan. Jalan Amal Lama Nomor 1 Tarakan. \\ Kalimantan Utara. \\ 2) Samko Timber Limited.
}

Corresponding author : jabarsyah@mail.com

Received 18 June 2016; Accepted 10 October 2016; Available online 29 November 2016

\begin{abstract}
We identified the species of "kerang kapah" (hard clam) using the Gel Electrophoresis SDS Page, in order to clarify the species of kerang kapah those found living along the East Coast of Tarakan Island. The study was conducted from July to December 2014. The kerang kapah were collected from the several parts of East Coast Tarakan Island. Eight group samples of kerang kapah were used for Gel Electrophoresis SDS Page and scanned using the IMAGE software. Generally, the kerang kapah those found at the shouth part of East Coast of Tarakan Island have very similar morphologies and shell colors, making species identification difficult. Four species of kerang kapah were identified. Three species belong to Veneridae and one species belong to Corbiludae. The species of Veneridae were Meretrix meretrix, Meretrix lyrata, and Meretrix sp. The species karang kapah belong to Corbiludae is Polymesoda erusa.
\end{abstract}

Keywords: kerang kapah, meretrix, polymesoda, gel electrophoresis.

\section{Pendahuluan}

Pantai Timur pulau Tarakan adalah pantai landai yang langsung berhadapan dengan laut Sulawesi dan merupakan kawasan wisata pantai yang banyak dikunjungi oleh masyarakat Kota Tarakan. Selain dijadikan kawasan wisata pantai, pantai ini juga merupakan lokasi untuk berbagai usaha perikanan, antara lain usaha penangkapan ikan, penangkapan udang dan penangkapan kerang-kerangan serta tempat budidaya rumput laut. Kerang-kerangan yang dijumpai di daerah ini adalah kerang tahu. Jenis lainnya yang juga dijumpai dalam jumlah yang sedikit adalah kerang kepah. Penduduk di daerah ini menyebut kedua jenis kerang ini dengan nama kerang kapah.

Dalam satu dasawarsa terakhir ini, kerang kapah sudah menjadi menu kuliner penting di Kota Tarakan khususnya di kawasan wisata pantai Timur pulau Tarakan. Usaha ini sudah menjadi usaha perikanan komersial dan telah memberikan keuntungan bagi masyarakat dan rumah tangga nelayan di wilayah ini. Namun usaha perikanan kerang kapah di wilayah ini belum mengarah pada usaha budidaya. Para nelayan masih mengandalkan kemampuan alam untuk memproduksi kerang kapah. Jika usaha penangkapan kerang dilakukan terus menerus, maka dikhawatirkan usaha perikanan kerang kapah di daerah ini akan mengalami masalah pada masa yang akan datang. Temuan terakhir menunjukan ada kecenderungan penurunan populasi kerang kapah di Pantai Amal. Dhimas et al., (2013) telah melakukan penelitian tentang pertumbuhan populasi kerang kapah di daerah ini yang dikumpulkan dari para pengepul. Hasil wawancara dengan pelaku usaha kerang kapah di pantai Amal menunjukan gejala penurunan produksi. Pada awal dimulainya usaha komersialisasi kerang kapah di pantai Amal pada tahun 2004, produksi kerang kapah dapat mencapai $200-300 \mathrm{~kg}$ 
per hari, setelah 10 tahun berjalan produksi tangkapan berkurang sampai $50 \%$.

Secara ekologi kerang kapah mendiami zona intertidal bersubstrat pasir berlumpur. Perairan pantai Timur pulau Tarakan lokasi dimana penelitian ini dilakukan, sebagian wilayah intertidalnya memiliki substrat dasar perairan yang berpasir, sebagian wailayah yang lain memiliki substrat dasar perairan yang berlumpur. Lingkungan perairan yang seperti ini merupakan habitat yang disukai oleh kerang kapah.

Secara umum ciri-ciri morfologi kerang tahu tahu dan kerang kepah dapat dengan mudah untuk dibedakan. Kerang tahu memiliki cangkang yang berwarna putih tahu dengan permukaan cangkang yang licin dan mengkilap. Pada sebagian cangkang kerang ini terdapat siluet berwarna hitam. Sedangkan kerang kepah memiliki cangkang yang berwarna gelap kehijauan. Kerang tahu mempunyai dua katub cangkang simetris dengan bentuk yang lebih straight mulai dari tepi cangkang sampai pada bagian punggung, sedangkan kerang kepah memiliki cangkang yang lebih cembung menyerupai cawan. Ciriciri morfologi antar jenis kerang kapah dalam genus satu sama lain sangat sulit untuk dibedakan terutama pada fase juvenil, sehingga sulit untuk diidentifikasi. Saat ini ada beberapa metode untuk mengidentifikasi perbedaan populasi antar species biota yang memiliki kekerabatan yang sangat dekat, antara lain dengan bio-molekuler atau dengan squencing DNA. Metode lain yang dapat digunakan untuk mengidentifikasi species kerang yang secara morfologi sulit untuk dibedakan adalah dengan penelusuran berat molekul protein melalui Gel Electrophoreis SDS Page.

\section{Metodologi Penelitian}

\section{Waktu dan lokasi sampling}

Penelitian ini dilakukan selama 6 bulan, yaitu sejak awal Juli sampai dengan akhir Desember 2014. Kerang contoh yang digunakan dalam penelitian ini berasal dari pantai Timur Pulau Takan. Lokasi sampling yang ditetapkan mulai perairan pantai Amal Lama, Amal Baru dan perairan pantai Binalatung. Analisis profil protein dilakukan di Laboratorium Jurusan Manajemen Sumberdya Perairan, Fakultas Perikanan dan IImu Kelautan, Universitas Borneo Tarakan.

\section{Pengambilan sampel}

Pengambilan contoh kerang menggunakan garuk besi berbentuk sisir dengan panjang sisir $45 \mathrm{~cm}$ dan lebar garuk $20 \mathrm{~cm}$. Kerang contoh diambil pada kedalaman $20-30 \mathrm{~cm}$ dalam area seluas 10 x $10 \mathrm{~m}$ pada pagi hari saat air sedang surut. Pengambilan contoh dilakukan setiap 2 minggu selama 6 bulan. Berat massa dan panjang cangkang diukur dan ditabulasi. Selain itu juga dilakukan pengukuran beberapa paramater lingkungan perairan yang akan digunakan sebagai data pendukung.

\section{Preparasi Sampel}

Protein yang digunakan dalam penelitian ini diambil dari otot aduktor kerang contoh. Otot aduktor dipisahkan dari daging yang lainnya kemudian dicuci dengan air destilasi. Pemisahan otot aduktor dilakukan secara hati-hati agar tidak terjadi kontaminasi. Masing-masing otot aduktor yang telah dipisahkan disimpan dalam tabung reaksi telah tambahkan dengan air destilasi sebanyak $1 \mathrm{ml}$ pada suhu dingin, kemudian diberi label. Otot aduktor dihomogenasi dengan menggunakan homogenizer pada Kecepatan 3000 rpm selama 1 menit. Hasil homogenasi dipindahkan ke dalam vial bin. Otot aduktor yang telah dihomogenasi diambil $5 \mu \mathrm{l}$ dan dipindahkan ke dalam tabung evendorf kemudian ditambah dengan larutan SDS, selanjutnya diekstrak dalam air mendidih pada suhu lebih kurang 900C selama 5 menit. Ekstrak otot aduktor disentrifugasi pada kecepatan 5000 rpm selama 3 menit. Supernatan dari hasil sentrifugasi dipindahkan ke dalam tabung evendorf.

\section{Gel elektroforesis sds page}

Supernatan yang disimpan dalam vial bin diambil dengan mikro-pipet dan alirkan secara vertikal pada $10 \%$ gel elektroforesis SDS Page selama 90 menit pada arus listrik $20 \mathrm{~mA}$. Kemudiansetelah proses tersebut di atas selesai maka $10 \%$ gel elektroforesis SDS Page tersebut distaining dengan menggunakan larutan BCB. Proses staining dilakukan di dalam tapper wear yang digoyang dalam water bath secara perlahan sampai band-nya terlihat jelas. Band yang terlihat pada $10 \%$ gel elektroforesis SDS Page dari hasil staining discanning untuk pengukuran 
optical Density-nya. Optical Density dari hasil scanning tersebut dibaca dengan menggunakan software "IMAGE". Software "IMAGE" dibuat oleh the National Institutes of Health, USA.

\section{Hasil dan Pembahasan}

\section{Parameter Lingkungan Perairan}

Pantai Timur pulau Tarakan merupakan pantai yang landai, pada saat pasang tertinggi kedalaman perairannya dapat mencapai 4 meter. Pantai ini merupakan daerah intertidal. Di sekitar pantai ini mengalir beberapa sungai kecil. Pada waktu-waktu tertentu perairan di pantai ini selalu bergolak dengan ketinggian ombak dapat mencapai 3 meter. Substrat dasar perairannya adalah berpasir dengan sedikit lumpur dan pada daerah tertentu di pantai ini substrat dasarnya berlumpur dengan sedikit pasir. Suhu perairan rata-rata pada saat cuaca cerah berkisar antara $26{ }^{\circ} \mathrm{C}$ to 28 ${ }^{\circ} \mathrm{C}$ pada pagi hari dan $28^{\circ} \mathrm{C}$ to $33{ }^{\circ} \mathrm{C}$ pada siang hari. Sedangkan salinitasnya berkisar antara $26 \%$ to $32 \%$. Kondisi lingkungan seperti yang digambarkan atas sangat dipengaruhi oleh cuaca dan aliran sungai yang ada di sekitarnya. Suhu dan salinitas merupakan parameter lingkungan yang sangat berperan dalam penyebaran biota air termasuk kerang-kerangan (Suja and Muthiah $P$, 2006). Kedua parameter ini menjadi pembatas tingkat aktifitas dan keseimbangan energi biota perairan (Ansell et al., 1980a; 1980b; 1981). Suhu juga mempengaruhi kemampuan kerang dalam menggunakan oksigen dari udara pada zona intertidal (Bayne dan Newell, 1983). Variasi suhu dan salinitas di pantai Timur pulau Tarakan tidak terlalu ekstrim dari waktu ke waktu sehingga tidak menjadi faktor yang dapat menghambat penyebaran dan aktifitas kerang di daerah ini. Kondisi lingkungan seperti ini tergolong sangat ideal untuk kehidupan berbagai jenis biota air, termasuk kerang-kerangan.

\section{Ukuran dan morfologi contoh kerang}

Panjang dan berat contoh kerang yang terkumpul diukur secara individu. Dari hasil pengukuran contoh didapatkan variasi ukuran panjang 4,2-8,5 cm dan berat 15,3-23,4 g. Fotografi kerang yang dikoleksi selama penelitian dapat dilihat pada Gambar 1 di bawah ini.

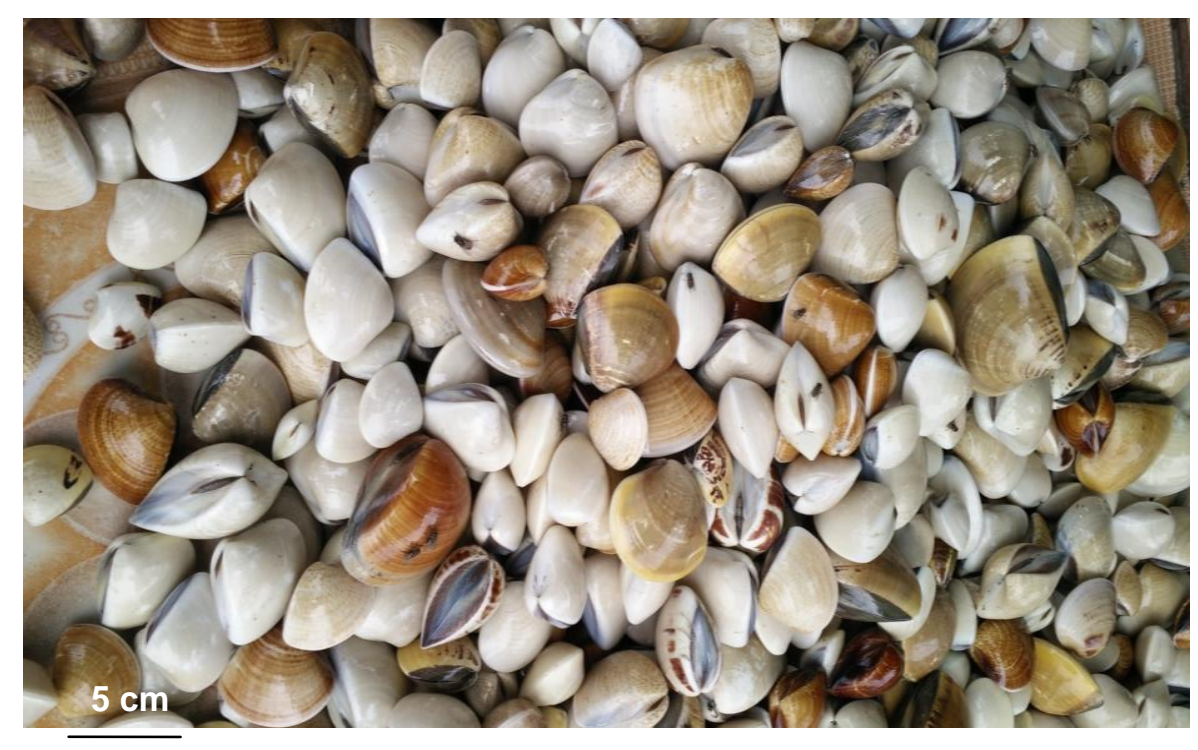

Gambar 1. Meretrix sp yang ditemukan di pantai Timur pulau Tarakan. 
Kepadatan kerang tahu di pantai Timur pulau Tarakan masih berkisar antara 800 $1200 \mathrm{ind} / 100 \mathrm{~m}^{2}$ dan yang terpadat ditemukan di pantai Amal Lama dan semakin ke utara semakina berkurang. Sampai saat ini belum ada data tentang kepadatan kerang di daerah ini yang dapat digunakan sebagai pembanding. Kepadatan kerang kapah yang ditemukan di daerah hutan mangrove yang terdapat di bagian Utara pantai Timur pulau Tarakan berkisar antara $15-38 \mathrm{ind} / 100 \mathrm{~m}^{2}$.

\section{Identifikasi Jenis Kerang}

Identifikasi jenis kerang dilakukan secara morfologi dengan cara mengamati bentuk dan pola ulir cangkangnya dibawah mikroskop cahaya pada pembesaran lensa 10x. Perbedaan bentuk, motif dan warna cangkang serta ciri-ciri morfologi lainnya dapat dilihat pada Gambar 2.

Berdasarkan bentuk cangkang, warna cangkang dan ulir cangkang serta bagian dalam cangkangnya terdapat beberapa perbedaan yang mencirikan masing-masing species. Species kerang kapah yang dengan mudah dapat dibedakan dengan kerang kapah yang lainnya adalah kerang kapah yang ditemukan di sebelah Utara pantai Timur Pulau Tarakan (Gambar $2 \mathrm{H}$ ). Kerang kapah yang ditemukan di tempat ini berwarna agak gelap dengan ulir cangkang luar dan bagian yang lebih kasar dibandingkan dengan kerang kapah yang ditemukan di bagian Selatan pantai Timur Pulau Tarakan, kerang ini juga dikenal sebagai kerang kepah (Polymesoda $s p$ ), oleh penduduk lokal juga disebut kapah. Kerang kepah memiliki sebaran yang sangat luas, tersebar mulai dari kawasan hutan mangrove di Indo-Pasifik sampai pada kawasan rawa mangrove di Amerika Selatan. Secara morfologi kerang kepah dapat dengan mudah dibedakan dengan kerang tahu. Kerang kepah mempunyai dua buah katup cangkang yang simetris dan kedua katub dihubungkan oleh hinge ligamen. Ciri-morfologi kerang ini antara lain, pipih dan tanjam pada bagian pinggir cangkangnya dan cembung pada bagian punggungnya serta cenderung menebal pada bagian yang mendekati ligamen.

Kerang yang ditemukan pada perairan pantai Amal Lama dan Amal Baru memiliki cangkang yang lebih halus dan licin dengan warna cangkang bangian luar yang lebih cerah dan mengkilap (Gambar 2 A, B, C dan G), kerang ini memiliki penyebaran yang sangat luas, mulai dari pantai semenanjung Korea sampai di kawasan pantai Asia Tenggara. Kerang ini menyukai habitat dengan substrat berpasir di daerah pasang-surut yang landai sampai pada kedalaman 20 meter. Secara morfologi kerang ini memiliki bentuk cangkang yang cenderung straight mulai dari bagian tepi cangkang menuju bagian punggungnya (Yamakawa dan Imai, 2012).

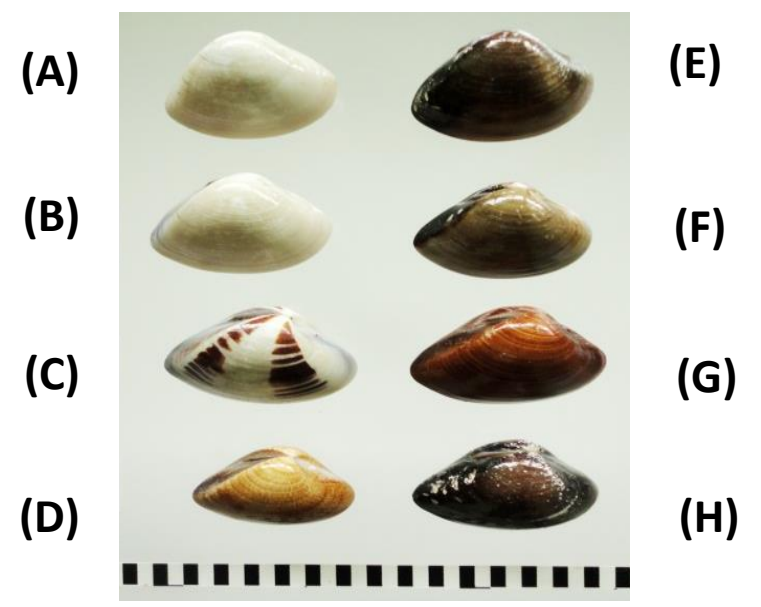

Gambar 2. Contoh Kerang contoh yang mewakili kelompok dan lokasi sampling. A-D ditemukan pada subtrat berpasir, E-F ditemukan pada subtrat berpasir dan berlumpur. G-H, ditemukan pada subtrat berlumpur 


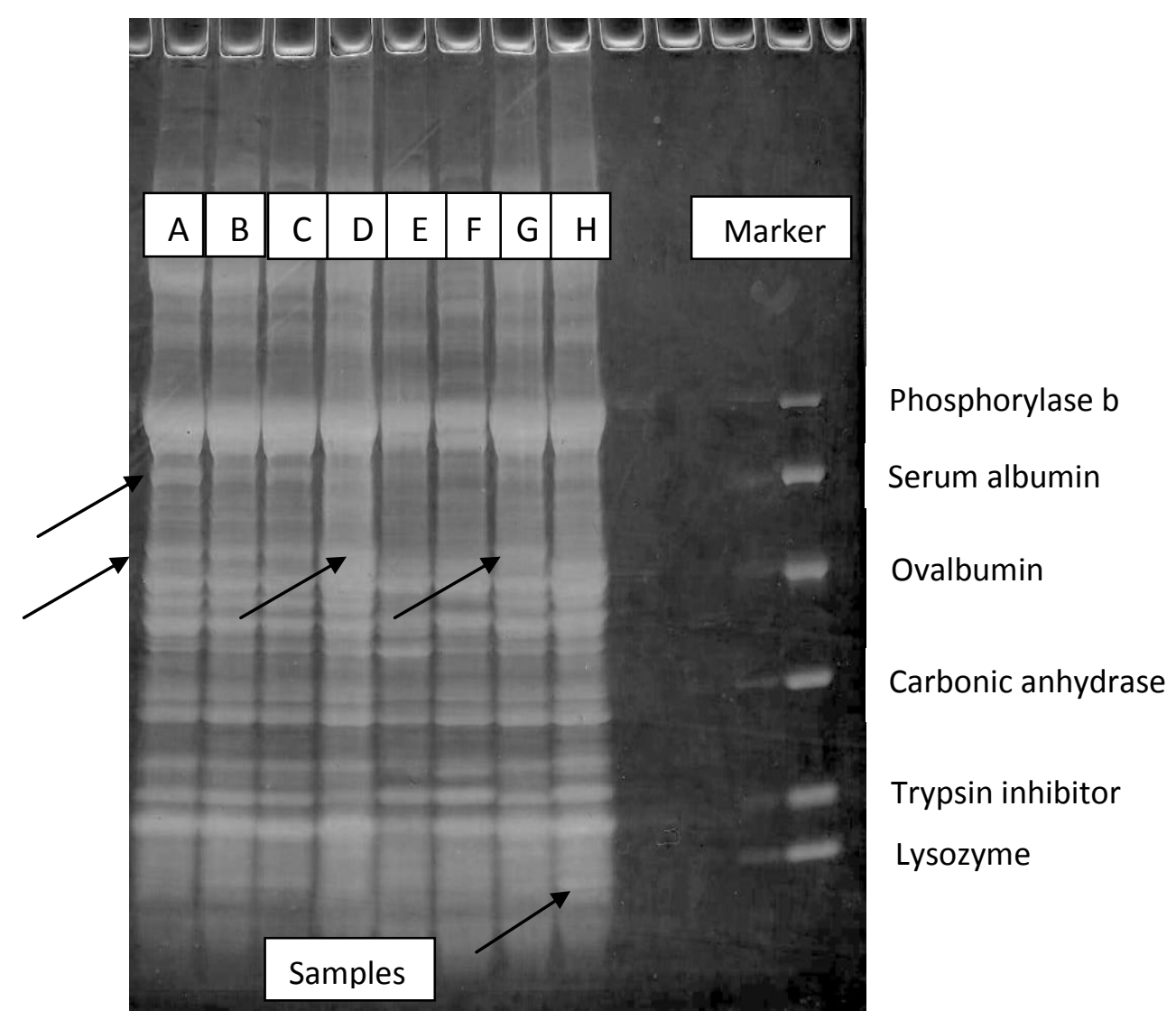

Gambar 3. Pola band Gel Electrophoresis SDS Page dari masing-masing kerang contoh dan standar protein yang digunakan dalam penelitian ini.

\begin{abstract}
Secara morfologi agak sulit membedakan species yang berasal dari genus Meretrix. Secara sepintas bentuk cangkangnya hampir sama, terutama pada fase-fase awal pertumbuhannya, walaupun warna cangkang berbeda bisa saja berasal dari species yang sama. Menelusuri pola band Gel Electrophoresis SDS Page dapat terlihat perbedaan antara satu sampel dengan sampel yang lainnya. Sampel A, B dan C memperlihatkan kesamaan posisi band yang dapat memberikan penjelasan bahwa mereka berasal dari species yang berbeda dengan $E$ dan $F$ serta sampel D dan $G$. Satu sampel $(\mathrm{H})$ yang sangat berbeda dengan yang lainnya, yaitu sampel yang ditemukan di kawasan hutan mangrove di sisi Utara pantai Timur pulau Tarakan, secara morfologi
\end{abstract}

memang berbeda dengan yang disebutkan di atas. Yang disebutkan terakhir menyukai habibat berlumpur di daerah estuaria yang banyak ditumbuhi hutan mangrove, kerang ini dikenal dengan nama kerang kepah (Polymesoda sp).

Gambar 4 berikut ini adalah hasil scanning dari $10 \%$ Gel Electrophoresis SDS Page di atas dengan menggunakan software "IMAGE". Soft ware "IMAGE" yang dihubungkan dengan layar komputer, grafik yang dihasilkan dari scanning tersebut dioverlay agar terlihat kesamaan dan perbedaannya, kemudian dari hasil overlay grafik tersebut temukan empat kelompok jenis kerang kapah seperti yang sajikan pada Gambar 4 berikut. 

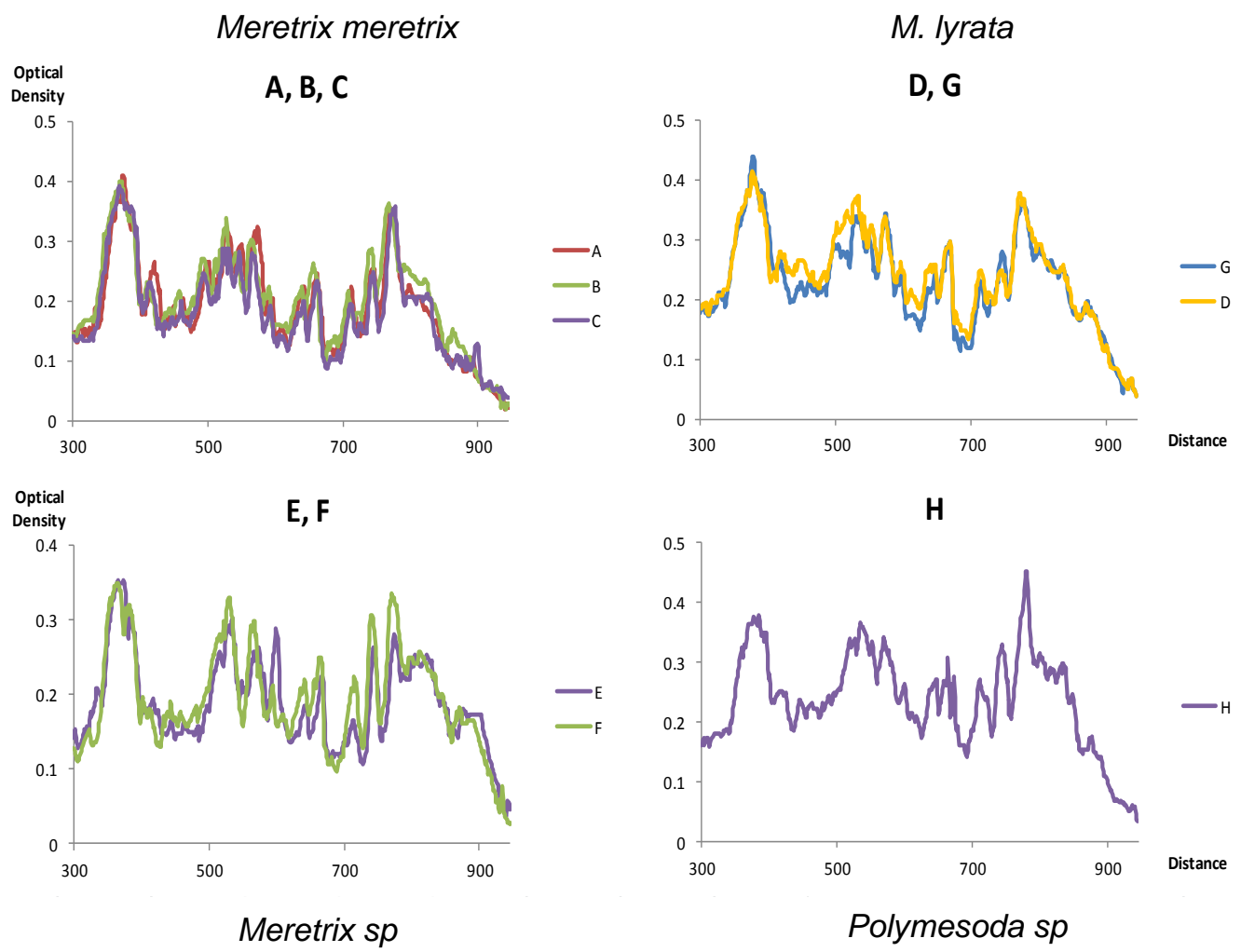

Gambar 4. Hasil scanning dari 10\% Gel Electrophoresis SDS Page di atas dengan menggunakan software "IMAGE".

Akhir-akhir ini identifikasi kerang secara genetik sudah banyak dilakukan, metode ini banyak dikembangkan di negara-negara maju. Metode ini dapat mengidentifikasi species kerang yang memiliki kekerabatan yang sangat dekat, misalnya kerang yang berasal dari Genus yang sama (Kim and Yoon, 2014). Peneliti lain, telah melakukan penelitian molekular terhadap species yang berasal dari Veneridae. Dengan scanning Gel Electrophoresis SDSPage ini juga dapat memberikan hasil yang akurat (Jung et al., 2004; Chen et al., 2009). Dari hasil penelitian ini ada empat species kerang yang yang ditemukan di perairan pantai Timur pulau Tarakan yang dapat diidentifikasi. Tiga species berasal dari genus Meretrix, yakni $M$. meretrix, M. lyrata, dan Meretrix sp. satu species dari Polymesoda adalah Polymesoda erosa.

\section{Daftar Pustaka}

Ansel, A.D., Barnet P.R.O., Bodoy A., Mase, H. 1980a. Upper Temperature tolerance of some European molluscs I
Telina febula and T. Tenuis. Marine Biology 58:33-39.

Ansel, A.D., Barnet P.R.O., Bodoy A., Mase, H. 1980b. Upper Temperature tolerance of some European molluscs II Dona vitatus, D. Semistriatus and $D$. trunculus. Marine Biology 58:41-48.

Ansel A.D., Barnet P.R.O., Bodoy A., Mase, H. 1981. Upper temperature tolerance of some European molluscs III Cardium glaucum, $C$. tuberculatus and $C$. edule. Marine Biology 65:177-183.

Bayne, B.L., Newell, R.C. 1983. Physiological energetics of marine moluscs. . In the Mollusca (ed. K.M. Wilbur), Vol 4. Part 1, pp. 407-515. Academic Press, New York.

Chen, A.H., Li, Z.X., Feng, G.N. 2009. Phylogenetic relation-ships of the genus Meretrix (Mollusca: Veneridae) based on mitochondrial $\mathrm{COI}$ gene sequences. Zoololy Research 30:233239. 
98 Omni-Akuatika Vol. 12 No. 2 November 2016 : 92 - 98

Kim, D.H., Yoon, J-M, 2014. Distances of three white clam (Meretrix lusoria) populations investigated by PCR analysis. Developpment and Reproduction 18 (2): 89-98.

Dhimas, W., Gazali, S., Firdaus M., Yusuf, M.Y., 2013. Pendekatan metode Von Bartalanffy untuk analisis pertumbuhan kerang kapah (Meretrix meretrix yang berasal dari pengepul Pantai Amal Kota Tarakan. Jurnal Akuatika 4 (2) : 102114.

Jung, H.T., Kim, J., Choi, S.D. 2004. Phylogenetic relationship of the five Korean Veneridae clams, Bivalvia, Veneroida according to morphological characters. Journal of Aquaculture 17:197-208.

Suja, N.,Muthiah, P. 2006. Effect of Salinity on the growth and survival of spat of Marcia opima (Gmelin). Journal of Marine Biological Association of the India 48 (2): 235-255.

Yamakawa, A.Y., Imai, H. 2012. Hybridization between Meretrix lusoria and the alien congeneric species $M$. petechialis in Japan as demonstrated using DNA markers. Aquatic Invasion 7(3):327336. 